$70+16$ sor $17^{7965}$

MEASUREMENT OF HEAT GENERATION RATE OF HIGHLY RADIOACTIVE CALCINED ALUMINA

RELEASED FOR ANNOUNGEMENT

IN NUCLEAR SCIENCE ABSTRACTS

D. W. Rhodes and M. E. Jacobson

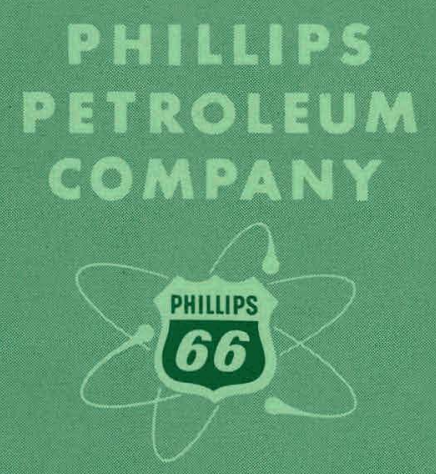

ATOMIC ENERGY DIVISION

NATIONAL REACTOR TESTINC STATION US ATOMIC ENERCY COMMISSION. 


\section{DISCLAIMER}

This report was prepared as an account of work sponsored by an agency of the United States Government. Neither the United States Government nor any agency Thereof, nor any of their employees, makes any warranty, express or implied, or assumes any legal liability or responsibility for the accuracy, completeness, or usefulness of any information, apparatus, product, or process disclosed, or represents that its use would not infringe privately owned rights. Reference herein to any specific commercial product, process, or service by trade name, trademark, manufacturer, or otherwise does not necessarily constitute or imply its endorsement, recommendation, or favoring by the United States Government or any agency thereof. The views and opinions of authors expressed herein do not necessarily state or reflect those of the United States Government or any agency thereof. 


\section{DISCLAIMER}

Portions of this document may be illegible in electronic image products. Images are produced from the best available original document. 
PRINTED IN USA. PRICE \$1.00. AVAILABLE FROM THE CLEARINGHOUSE FOR FEDERAL SCIENTIFIC AND TECHNICAL INFORMATION, NATIONAL BUREAU OF STANDARDS,

U. S. DEPARTMENT OF COMMERCE, SPRINGFIELD, VIRGINIA

\section{LEGAL NOTICE}

This report was prepared as an account of Government sponsored work. Neither the United States, nor the Commission, nor any person acting on behalf of the Commission:

A. Makes any warranty or representation, express or implied, with respect to the accuracy, completeness, or usefulness. of the information contained in this report, or that the use of any information, apparatus, method, or process disclosed in this report may not infringe privately owned rights; or

B. Assumes any liabilities with respect to the use of, or for damages resulting from the use of any information, appatatus, methud, ur prucess diselused in this sepöit.

As used in the above, "person acting on behalf of the Commission" includes any employee or contractor of the Commission, or employee of such contractor, to the extent that such employee or contractor of the Commission, or employee of such contractor prepares, disseminates, or provides access to, any information pursuant to his employment or contract with the Commission, or his employment with such contractor. 


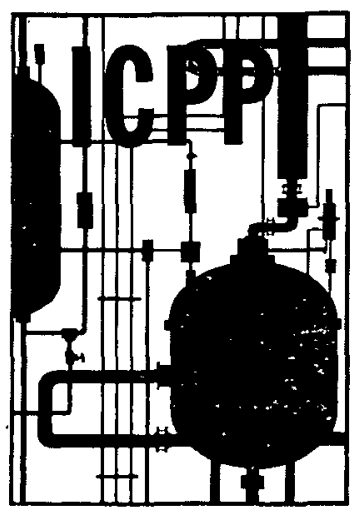

$I D O-14665$

AEC Research and Development Report

Waste Disposal and Processing

TID-4500, Ed. 44

Issued: October 1965

\section{RETLEASED FOR ANNOUNCEAGENT}

IN IMUCTMAR SCIENICE A.BSTRACTS

\section{MEASUREMENT OF HEAT GENERATION RATE OF HIGHLY \\ RADIOACTIVE CALCINED ALUMINA}

by

D. W. Rhodes and M. E. Jacobson

\section{$\cdots \quad$ LEGAL. NOTICE}

This report was prepared as an account of Government sponsored work. Nelther the Untted States, nor the Commission, nor any person acting on behalf of the Commission:

A. Makes any warranty or representation, expressed or implied, with respect to the accuracy, completeness, or usefulness of the information contalned in this report, or that the use of any Information, apparatus, method, or process disclosed in this report may not infringe privately owned rights; or

B. Assumes any liabllitles whth respect to the use of, or for damages resulting from the use of any Information, apparatus, method, or process disclosed in this report.

As used in the sbove. "person acting on behail of the Commission" Includes any employee or contractor of the Commission, or employee of such contractor, to the extent that such employee or contractor of the Commission, or employee of such contractor prepares, disseminates, or provides access to, any information pursuant to his employment or contract with the Commission, or his employment with such contractor.

\section{PHILLIPS}

PETROLEUM

COMPANY

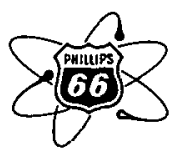

Atomic Energy Division

Contract AT(10.1).205 Idaho Operations Office 


\section{ACKINOWLEDGEMENT}

The authors express their appreciation to F. W. Roberts and J. P. Morgan of the Ceneral Maintenance Section for their assistance in building and calibrating the electrical circuits and Dr. C. M. Slansky of the Nuclear and Chemical Technology 'l'echnical Staff for his helpful suggestions and advice in designing and operating the equipment. 


\title{
MEASUREMENT OF HEAT GENERATION RATE OF HIGHLY \\ RADIOACTIVE CALCINED ALUMTNA
}

by

D. W. Rhodes and M. E. Jacobson

\begin{abstract}
$\underline{A} \underline{B} \underline{\mathrm{S}} \underline{T} \underline{\mathrm{R}} \underline{\mathrm{A}} \underline{\mathrm{C}} \underline{\mathrm{T}}$
The heat generation rate of highly radioactive solid waste must be known to design storage facilities for the waste. The calorimetric measurement of the heat generation rate of highly radioactive ( $\sim 20$ curies per pound) calcine produced by the fluidized bed calcination of aluminum nitrate-nitric acid wastes in the Waste Calcining Facility at the Idaho Chemical Processing Plant is described. The results agreed closely with values calculated by using the concentration, decay patterns, and decay energies of the radioisotopes in the waste.
\end{abstract}


MEASUREMENT OF HEAT GENERATION RATE OF HIGHLY

RADIOACTIVE CALCINED ALUMTIVA

by

D. W. Rhodes and M. E. Jacobson

TABLE OF CONTENTS

Page

ABSTRACT. . . . . . . . . . . . . . . . . i ii

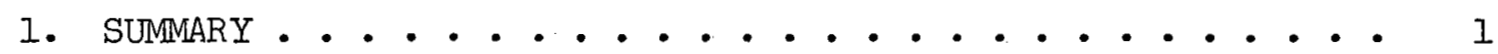

L. LNIRUDUCIIIUIN . . . . . . . . . . . . . . . . . I

III. EXPERTMENTAL EQUIPMENTT AND PROCEDURES . . . . . . . . . 2

I. Calorimeter and Tank Details . . . . . . . . . 2

2. Contrul and Heating Clrcult. . . . . . . . . 4

IV. EQUIPMENT CHECKOUT. . . . . . . . . . . . . 6

1. Procedure. .................. 6

2. Experimental Results ............. 6

V. MEASUREMEIVT OF HEAT GENERATION RATE OF RADIOACTIVE CAICINE. • 6

1. Procedure. . . . . . . . . . . . . . . . 6

2. Experimental Results . . . . . . . . . . 7

3. Comparison of Measured and Calculated Heat Generation

Rates..................... 9

VI. CONCLUSIONS . . . . . . . . . . . . . 10

VII. REFERENCES . . . . . . . . . . . . . . . . . 12

Table No.

\section{IIST OF TABLES}

I Heat Capacity of the Lead Calorimeter as Determined by Electrical Heating. . . . . . . . . . . . 7

II Calculated Heat Capacity of Lead Calorimeter . . . . 8

III Measured Heat Generation Rate of Highly Radioactive Calcined Alumina (April 1965)........... 10 


\section{LIST OF TABLES (Continued)}

Table No.

$\underline{\text { Page }}$

IV Radioisotopic Composition and Calculated Heat

Generation Rates of Calcined Alumina. . . . . . .

\section{LIST OF FIGURES}

Figure No.

Page

1 Calorimeter equipment - lead sphere and stainless steel vacuum vessel................ . . 3

2 Cutaway view of calorimeter and accessory equipment . .

3 Thermistor bridge circuit and water bath heater control circuit.................. 5

4 Rate of temperature increase of lead calorimeter containing WM-187 calcine . . . . . . . . .

5 Rate of temperature increase of lead calorimeter using WM-185 and WM-187 waste . . . . . . . . 


\section{MEASUREMENT OF HEAT GENERATION RATE OF HIGHLY RADIOACTIVE CALCINED ALUMINA}

by

D. W. Rhodes and M. E. Jacobson

\section{SUMMARY}

The heat generation rate of highly radioactive solid waste must be known to design storage facilities of the proper size. The heat generation rate of highly radioactive ( 20 curies per pound) calcine produced by the fluidized bed calcination of aluminum nitrate-nitric acid waste in the Waste Calcining Facility (WCF) at the Idaho Chemical Processing Plant (ICPP) was determined calorimetrically.

A calorimeter, constructed of lead to absorb the gamma rays, was filled with about one pound of calcine, and the rate of increase of the temperature of the lead calorimeter and its contents was measured in an adiabatic system. To maintain adiabatic conditions, the temperature difference between the lead calorimeter and its surroundings was held to less than $\pm 0.0003^{\circ} \mathrm{C}$ during the measurement.

The heat generation rates of two different batches of calcine produced from two different wastes were found to be 0.343 and 0.303 $\mathrm{Btu} / \mathrm{hr}-\mathrm{lb}$. Evaluation of the errors of measurement and standardization indicated these values to be within two percent of the true value; they were also within about three percent of the value calculated from the concentrations, decay patterns, and decay energies of the radioisotopes in the waste.

\section{INTRODUCTION}

The radioactive decay occurring during long-term storage of highly radioactive solid wastes must be considered in the design of properly sized storage facilities to avoid undesirably high temperatures. $\Lambda \mathrm{n}$ accurate value for the heat generation rate is required to determine the section thickness in the storage bin permissible for a given centerline temperature limit and heat transfer conditions. The rate of heat generation of highly radioactive calcine produced in the WCF(I) has been 
routinely calculated using the chemically analyzed concentration of each radioisotope in the waste together with data available on decay patterns and decay energies; however, no experimental measurement has been made. To measure accurately the heat generation rate of highly radioactive alumina, an adiabatic calorimeter was constructed of lead to absorb the gamma rays. The rate of temperature rise of the lead was then determined under adiabatic conditions.

\section{EXPERIMENTAL EQUIPMENT AND PROCEDURES}

The experimental technique used to obtain the rate of rise of the temperature of the lead calorimeter was an adaptation of an adiabatic technique that has been used to determine the disintegration rate of specific radioisotopes $(2,3)$. The differential equation describing the system is:

$$
P=C_{p} \frac{d \theta}{d t}+K \Theta^{\prime}
$$

Equation (1)

where, $P=$ the amount of heat per unit time produced by the absorbed radialivii

$$
\begin{aligned}
\frac{d \theta}{d t}= & \text { rate of increase of the temperature of the calorimeter } \\
\theta^{\prime}= & \text { the temperature difference between the calorimeter and its } \\
& \text { surroundings } \\
\mathrm{C}_{p}= & \text { the heat capacity of the calorimeter } \\
K= & \text { the rate of heat Loss per unit temperature difference. }
\end{aligned}
$$

By making the heat loss zero by maintaining the temperature of the surroundings at essentially the same temperature as the calorimeler $\left(\theta^{\prime} \cong 0\right)$, the differential equation becomes:

$$
P=C_{p} \frac{d \theta}{d t}
$$

Equation (2)

The value for $d \theta / d t$ is obtained from a plot of temperature vs time, and $\mathrm{C}_{\mathrm{p}}$ can be determined experimentally by supplying a known amount of electrical heat to the calorimeter or it can be calculated from the weights and specific heats of the component parts of the calorimeter.

\section{Culorimeter ark Tunk Deluile}

The calorimeter vessel is a lead sphere, seven inches in diameter with a four-inch diameter hollow center for holding the calcined alumina. A schematic diagram of the sphere Inside the vacuum vessel is shown in Figure 1 . I'he outside of the splere was spraycd with a bright silver paint to serve as a heat reflector, and a one-half inch diameter hole was drilled and tapped through the sphere to the hollow center to serve as an entry for the granular alumina. A threaded stainless steel plug was inserted to close the opening during operation. The lead sphere 


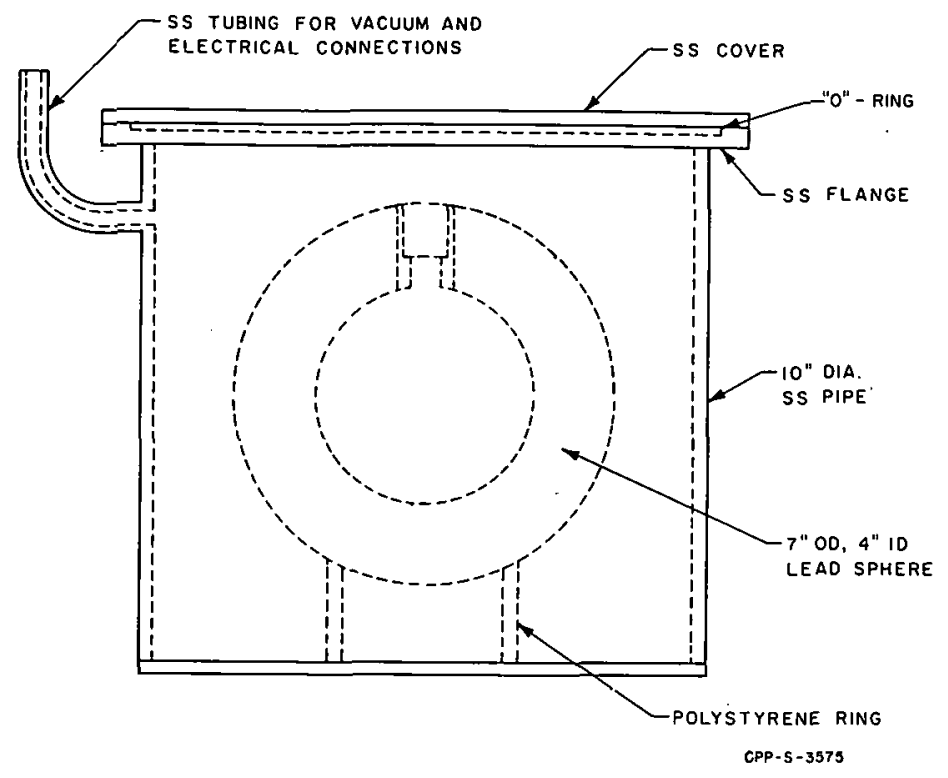

Fig. 1 Calorimeter equipment - lead sphere and stainless steel vacuum vessel

was supported inside a stainless steel vacuum vessel by a polystyrene ring, which insulated the sphere from the vessel. The flanged vacuum vessel was sealed by bolting a stainless steel cover to the flange which contained a neoprene " $O$ " ring recessed in a groove. A one-half inch diameter stainless steel tube was connected to the vacuum vessel and to a vacuum pump. It was used both as a vacuum line and as a container for the necessary instrument wiring.

'l'he vacuum vessel was immersed in approximately the center of a large ( 200-gallon) water bath and was supported on a slab of fourinch thick polystyrene placed on top of two concrete blocks. The water bath was insulated with a three-inch thickness of polystyrene, and the water bath and polystyrene insulation were encased in a three-fourth-inch thick: plywood box. The box with its contents was housed in a plywood shelter, which minimized convection currents within the room. A cutaway view of the entire assembly is shown in Figure 2.

The water bath was heated by three 100-watt heaters and one 50-watt heater located on the bottom of the bath and spaced equidistant around the calorimeter on a three-foot diameter ring. The three 100-watt heaters were used for the coarse heat adjustment, and the 50-watt heater for the fine heat adjustment. A $100-r p m$ stirring motor with double blades on the shaft stirred the bath. One blade was positioned below the vacuum vessel and the other blade near the top of the vessel as shown in Figure 2. Temperature readings taken at several points in the water bath indicated that the stirring produced uniform temperatures throughout the bath. Consequently, a temperature reading was taken from only one point in the water bath during the heat generation rate measurements. 


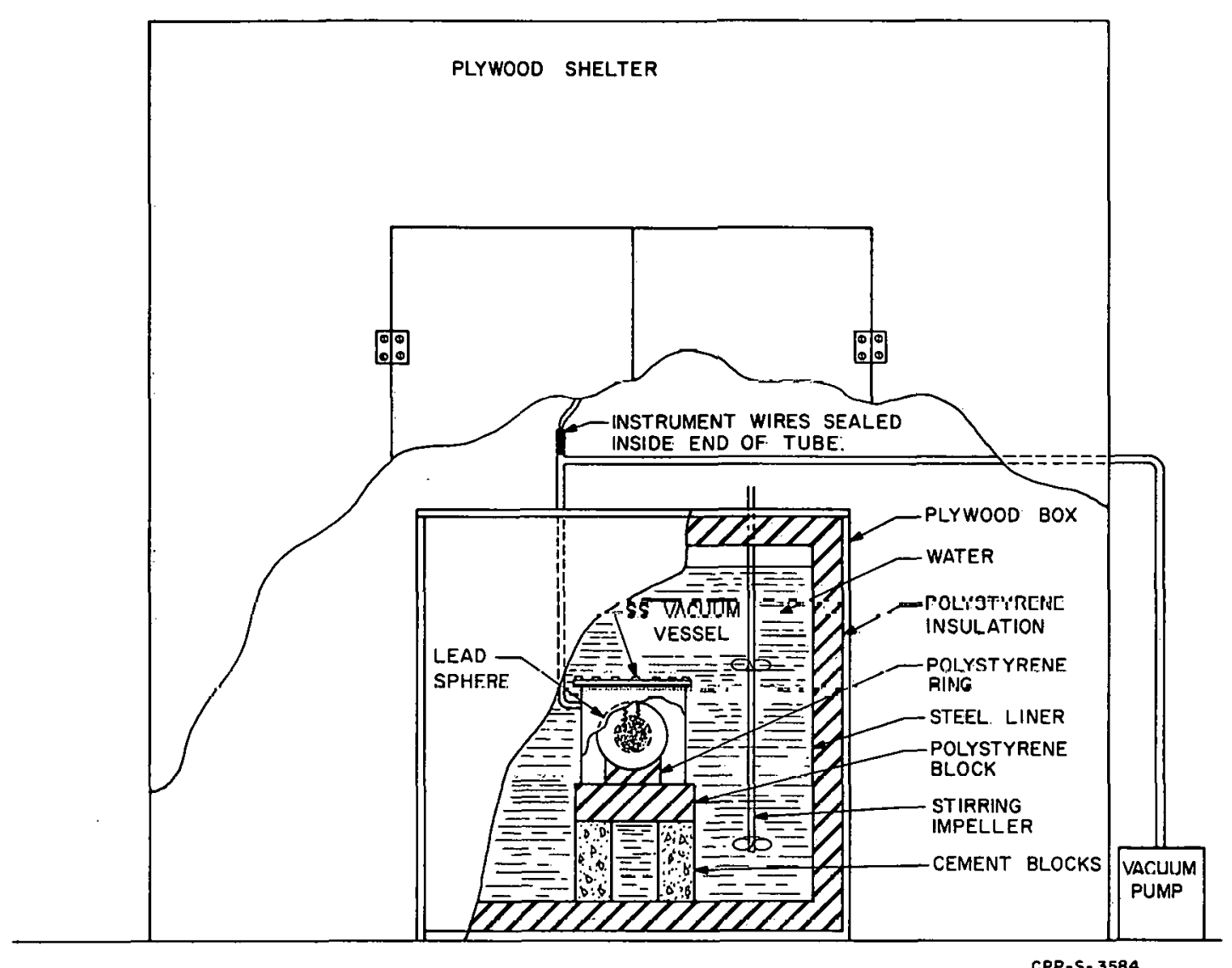

Fig. 2 Cutaway view of calorimeter and accessory equipment

\section{Control and Heating Circuit}

The control circuit consisted of a Wheatsone bridge circuit as shown in Figure 3. Four matched precision thermistors connected in scries formcd cach of two lcgo. Onc sct of four thcrmistors was placcd in a horizontal plane on the lead sphere $90^{\circ}$ apart. The other set was placed on the wall of the stainless steel vessel, opposite each of the thermistors on the lead sphere. The other two legs of the bridge were formed by two 40,000-ohm resistors, RI and R'2 in Figure 3. The bridge was bolanced by two variable resistors; a fifty-ohm variable resistor (R3) for a coarse balance, and a ten-ohm variable resistor (R4) for the fine balance.

The thermistors were the only parts of the bridge that were located inside the vacuum vessel. The bridge supply current (two mercury cells) and the rest of the circuit were enclosed in a separate box located adjacent to the plywood shelter with the other instruments.

The initial balancing of the system was accomplished by allowing all components to come to thermal equilibrium in the constant temperature bath. Then, when the experimental run was started, any temperature difference between the thermistors on the lead sphere and the thermistors on the vacuum vessel was sensed by the differential voltmeter. The signalled voltage difference, amplified through the meter circuit, was 


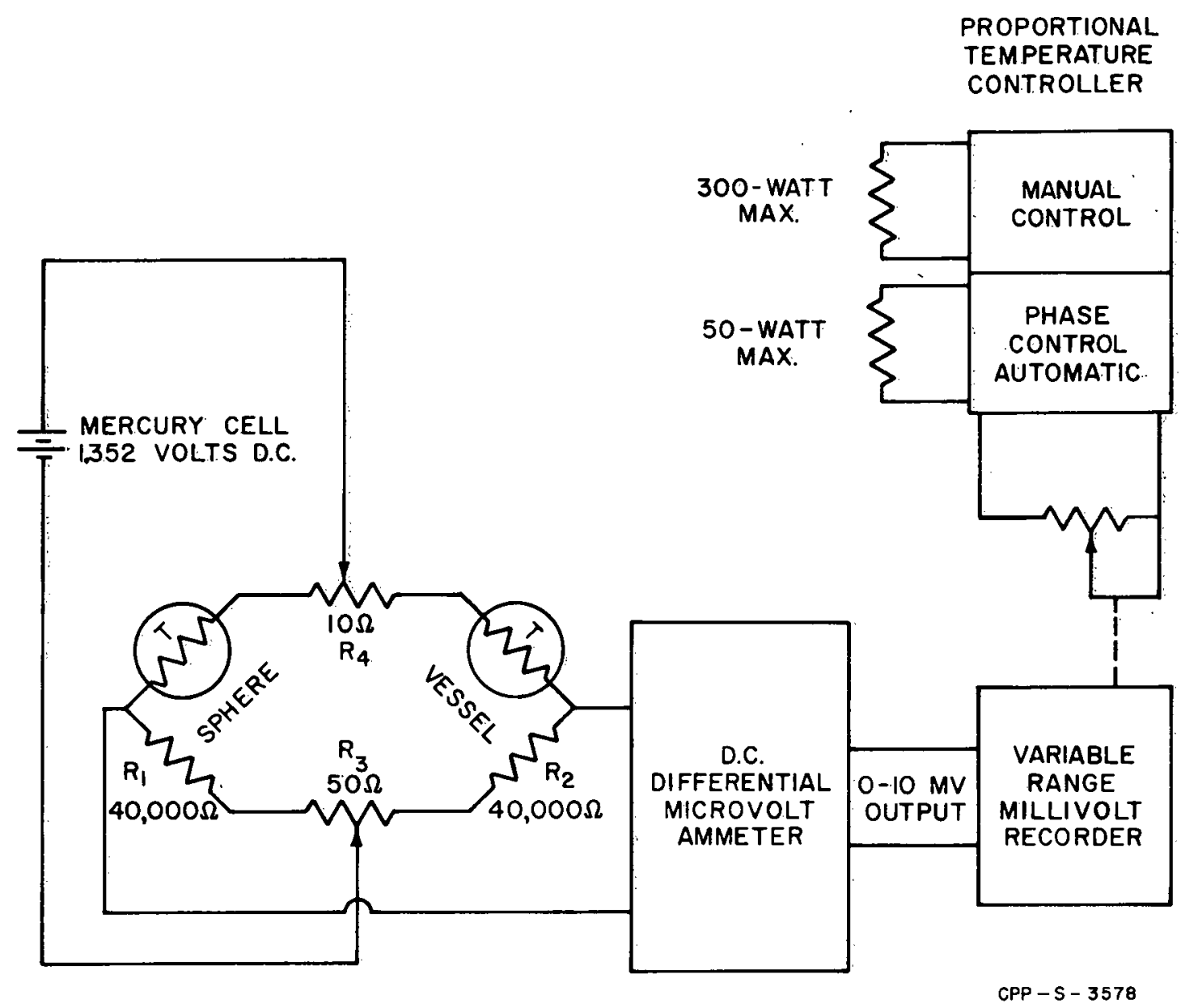

Fig. 3 Thermistor bridge circuit and water bath heater control circuit

fed into a varlable range millivolt recorder. A 10,000-ohm potentiometer, gear-driven from the recorder pen drive pully, was then used to transmit a control signal to a proportional temperature controller for supplying heat to the water bath. The coarse feed adjustment to the three 100-watt liealers was simply and rapidly controlled manually. Any change in the temperature of the water bath was evident immediately on the recorder chart. The fine control was then automatically controlled through the 10,000-ohm potentiometer by the deflection of the recorder pen from the zero point. Very rapid and accurate temperature control by this system was obtained; the maximum difference in temperature between the lead sphere and the vacuum vessel on all runs was $\pm 0.0003^{\circ} \mathrm{C}$, and most of the time it was $\pm 0.0002^{\circ} \mathrm{C}$.

It should be emphasized that the temperature of the lead sphere was obtained by reading the temperature of the water bath directly. Inasmuch as temperature readings taken at several points in the water bath during the first run Indicated that the stirring produced uniform temperatures, readings were taken from only one point during subsequent runs. These readings were used for all of the calculations. 
An additional circuit was installed to allow direct monitoring of the thermistors in the lead sphere and the vacuum vessel. A switch in the circuit permitted a direct reading of the resistance to be made for either the lead sphere or the vessel. This extra circuit is not essential for operation of the equipment and could be eliminated. A run made after the plywood shelter had been dismantled indicated that temperature fluctuations in the room did not detectably affect the resuilts; therefore the plywood shelter was probably unnecessary also.

\section{EQUTPMEIVT CHECKOUT}

\section{Procedure}

To test the reliability of the equipment, a 14.6-ohm resistance heater connected to a 3-volt d.c. power supply was placed inside the lead sphere, and the void in the lead sphere was filled with a light mineral oil to serve as a heat transfer medium. In making the test runs, the system was first allowed to come to thermal equilibrium; then the vacuum vessel was evacuated to less than 20 microns of mercury, and the heat input circuit was set to provide the desired heat input. As the temperature of the lead vessel increased, the temperature of the water. bath was raised to essentially the same temperature, first by the manual coarse control, then by the automatic fine control. Water bath temperature readings were taken as soon as the differential voltmeter, shown in Figure 3, indicated a nearly zero temperature differential between the lead sphere and the vacuum vessel. The maximum variation of this temperature differential during a run was $+0.0003^{\circ} \mathrm{C}$. 'l'hree test runs were made at power inputs of $0.319,0.52 \overline{2}$, and $0.634 \mathrm{Btu} / \mathrm{hr}$, which bracketed the heat generation rate of the radioactive solids.

\section{Experimental Results}

The heat capacity of the calorimeter containing the 14.6-ohm resistance heater and light mineral oil was calculated ror each test rur from Equation (2). The results are shown in Table $I$. The value obtained by measuring the heat capacity is in good agreement with the calculated value, thus substantiating the reliability of the calorimeter.

\section{MEASUREMENT OF HEAT GENERATION RATE OF RADIOACTIVE CAICLNE:}

\section{Procedure}

The void in the lead sphere was filled with radioactive solids by a remote handling technique. These solids had been prepared in the WCF by calcining aluminum nitrate-nitric acid waste that had been aged for several years $(1)$. The entry hole was then closed tightly with a stainless steel plug, and the unit placed in the water bath. Greater than 99 percent of the gamma radiation was absorbed in the lead sphere 
Table. I

HEAT CAPACITY OF THE LEAD CALORIMETER

AS DETERMTNED BY ELECTRICAL HEATIING

\begin{tabular}{cccc}
\hline Run No. & $\frac{\mathrm{d} \theta / \mathrm{dt}}{\left.{ }^{\circ} \mathrm{C} / \mathrm{hr}\right)}$ & $\frac{\text { Heat Input }(\mathrm{a})}{(\mathrm{Btu} / \mathrm{hr})}$ & $\frac{\text { Heat Capacity }}{\left(\mathrm{Btu} /{ }^{\circ} \mathrm{F}\right)}$ \\
1 & 0.080 & 0.318 & 2.21 \\
2 & 0.133 & 0.502 & 2.19 \\
3 & 0.154 & 0.635 & 2.29 \\
& & Average & 2.23 \\
$\begin{array}{l}\text { Calculated from the specific heats and weights } \\
\text { of the lead oil, and stainless steel fitting }\end{array}$ & 2.17 \\
\hline
\end{tabular}

as indicated by direct radiation measurements. The procedure for the runs using radioactive solids was essentially the same as for the test runs, but of course the electrical power input was not required. The heat capacity of the calorimeter, which was determined in the test runs, could not be used for calculating the heat generation rate for the runs with radioactive calcine because the void space in the lead sphere during the "hot" runs was filled with alumind instead of oil. However, the specific heats for the component parts of the calorimeter are accurately known, so the heat capacity is easily calculated by multiplying the weight of the component part by the specific heat for the material as shown in Table II. The calculated heat capacity for the calorimeter for the two different wastes, WM-187 and WM-185, was different only because there was a different amount of alumina used in each test.

2. Experimental Results

The results of the heat generation measurements using radioartive calcincd alumina ( 20 curles/1b) were obtained from: (1) four short runs of about 6 hours duration with waste WM-187, (2) one long run of ahnut 46 hourc with waste WM-187, and (3) a single long run of 52 hours with waste WM-185. The data for all of the runs are shown in Figures 4 and 5 and in Table III. The straight lines in the figures represent the "best straight lines" as determined by regression analysis. The deviation from the straight line at the 99 percent confidence level varled from 0.8 to 1.6 percent for the six-hour runs and was only about 0.2 percent for each of the long runs. 
Table II

CALCULATED HEAT CAPACITY OF LEAD CALORTMETER

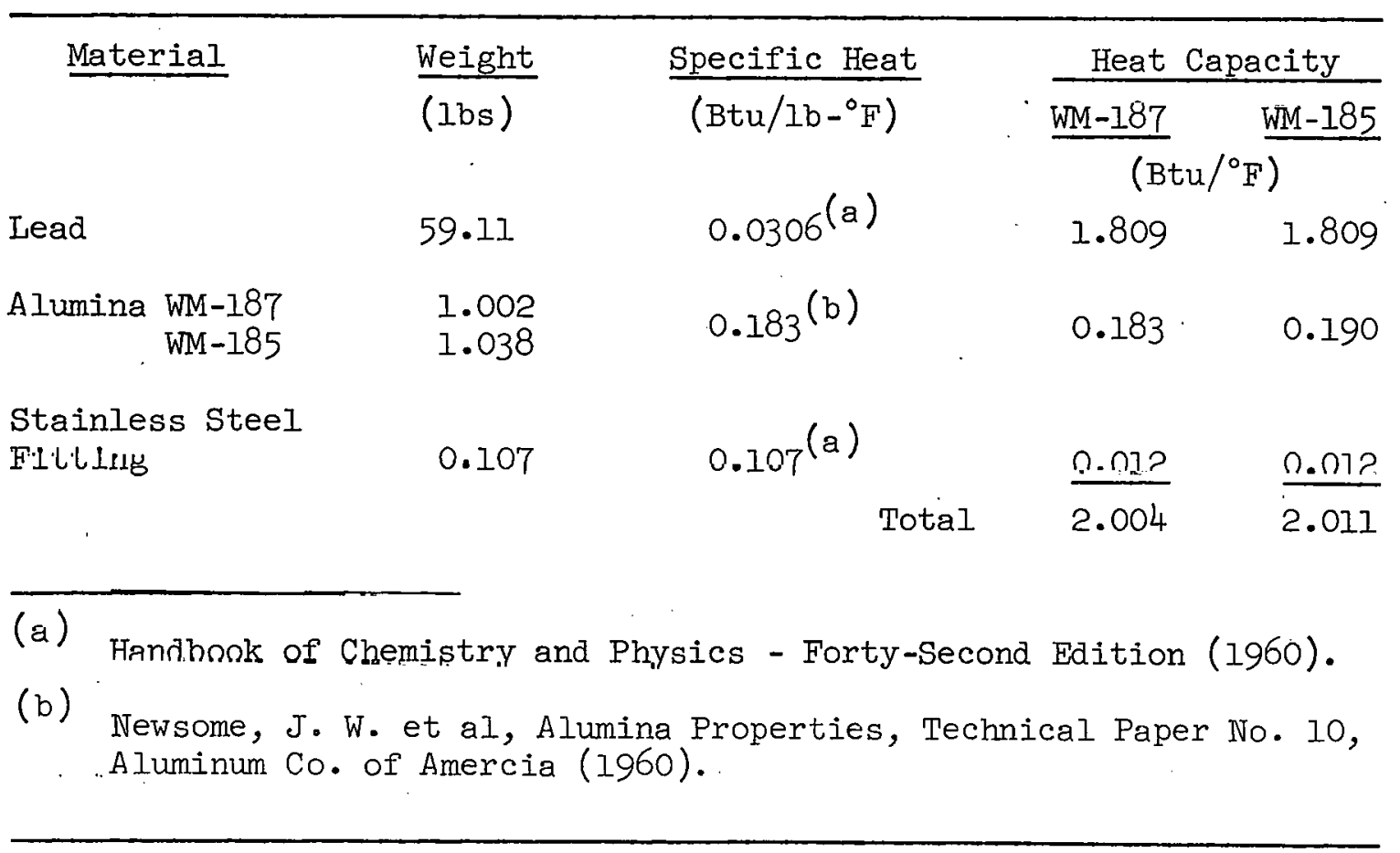

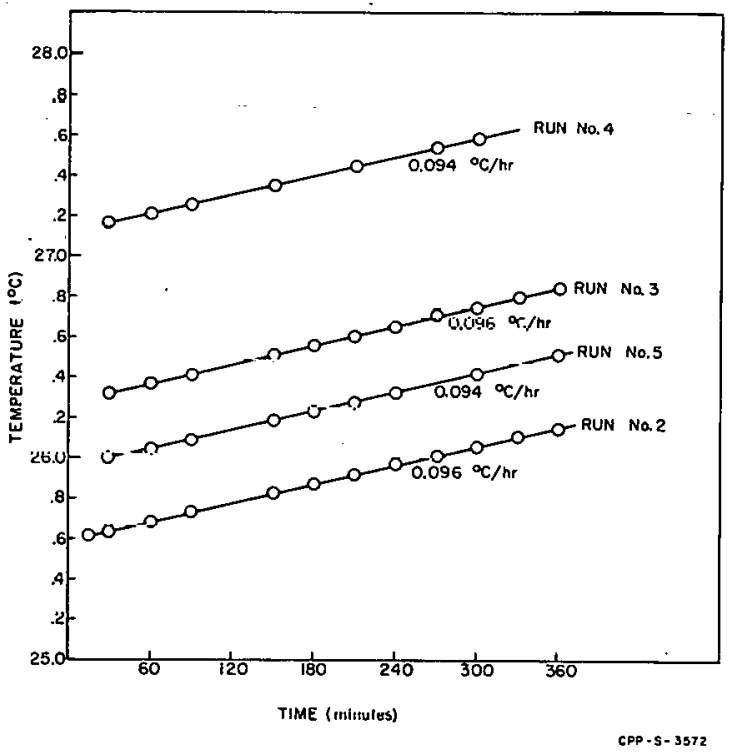

Fig. 4 Rate of temperature increase of lead calorimeter containing WM-187 calcine 


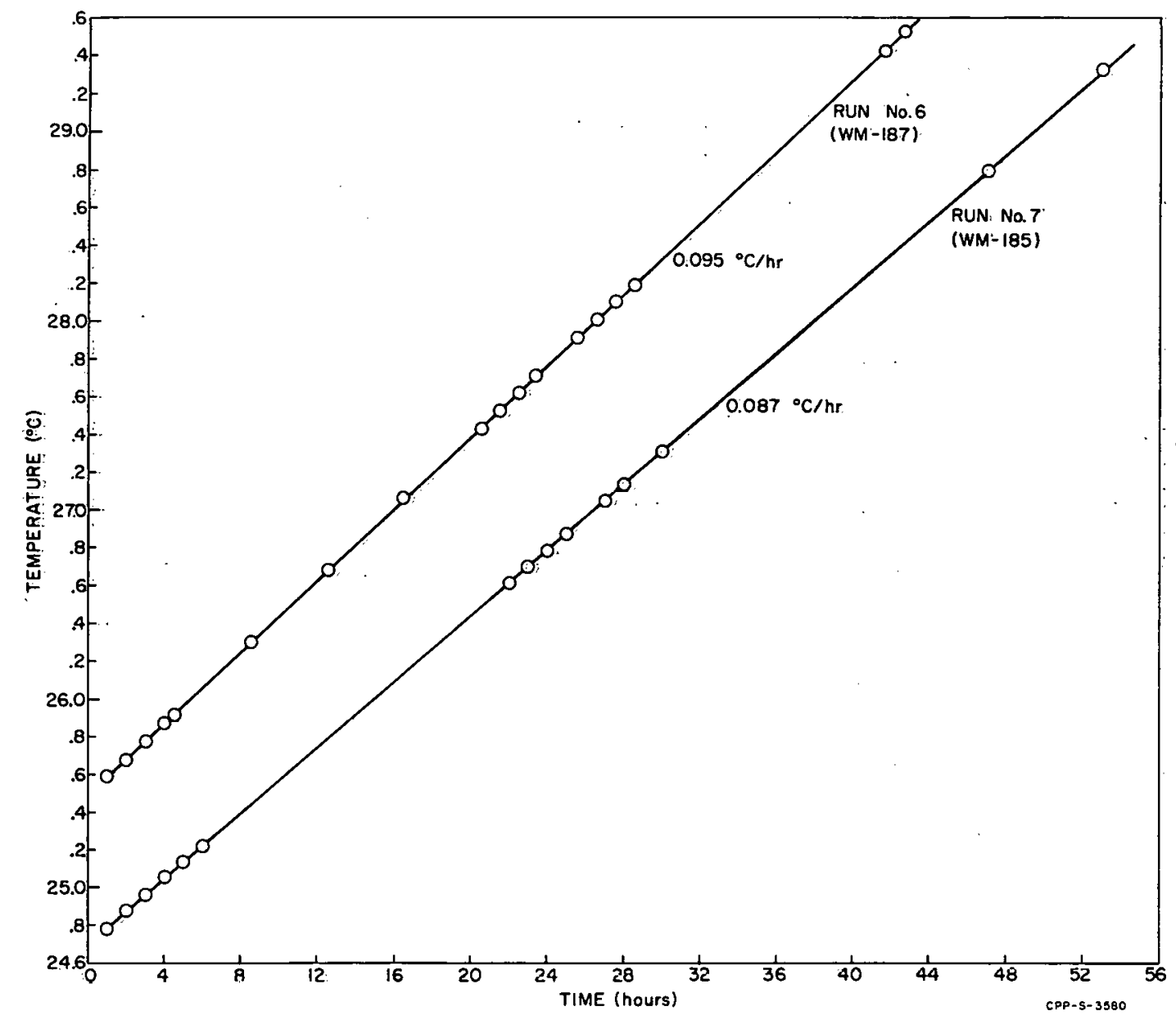

Fig. 5 Rate of temperature increase of lead calorimeter using WM-185 and WM-187 waste

An estimate of the errors was made using the temperature measurement error at the 99 percent confidence level and the specific heat and weight errors as being \pm 5 in the next significant figure beyond that listed in Table II. These results indicated that the error was +0.004 Btu/hr, or about one percent.

\section{Comparison of Measured and Calculated Heat Generation Rates:}

The radioisotopic compositions of the two highly radioactive calcined alumina wastes used for the heat generation measurements and their calculated heat generation rates are shown in Table IV. For comparison, the measured heat generation rates are also given in this table. As can be seen, the agreement is reasonably good; the measured heat generation rates were 3.2 and 0.3 percent higher than the calculated values for the WM-187 and WM-185 wastes, respectively. 
Table III

MEASURED HEAT GENERATION RATE OF HIGHLY RADIOACTIVE CALCINED ALUMINA (APRIL 1965)

\begin{tabular}{|c|c|c|c|c|}
\hline Waste No. & Run No. & $\begin{array}{l}\text { Length } \\
\text { of Run }\end{array}$ & $a \theta / d t$ & $\begin{array}{c}\text { Measured Heat } \\
\text { Generation Rate }\end{array}$ \\
\hline & & $(h r s)$ & $\left({ }^{\circ} \mathrm{C} / \mathrm{hr}\right)$ & $(B+u / h r-I b)$ \\
\hline WM-187 & $\mathrm{H}-2$ & 6 & 0.096 & 0.346 \\
\hline WM- 187 & $\mathrm{H}-3$ & 6 & 0.096 & 0.346 \\
\hline WM-187 & $\mathrm{H}-4$ & 6 & 0.094 & 0.340 \\
\hline \multirow[t]{2}{*}{ WM-187 } & $\mathrm{H}-5$ & 6 & 0.094 & 0.340 \\
\hline & & & Averabe & 0.543 \\
\hline WM-187 & $\mathrm{H}-6$ & 46.5 & 0.095 & 0.343 \\
\hline WM-185 & $\mathrm{H}-7$ & 53 & 0.087 & 0.303 \\
\hline
\end{tabular}

VI. CONCLUSIONS

The adiabatic system used for the heat gereralion measurements functioned smoothly and accurately. Additional sensitivity, if needed, could be obtained by using more responsive thermistors and a rore sensitive temperature reading device t'or the water bath. ilhe measuremenls made with the present equipment were estimated to be within two percent of the true value which is entirely adequate for designirig storage bins for the calcine. Furthermore, the comparison of the measured values with the values calculated from radiochemical analyses indicates that the latter, at least on waste aged for a few years, are reliable. As firesher waste is used, however, additional radioisotopes contribute to the heat generation; consequently, the chance for error in the calculated value increases. In future work, heat generation measurements of calcined alumina prepared from fresher wastes and of calcined zirconia and stainless steel oxide wastes will be made in the same equipment. 
Waste No. WM-187. (April 1965)

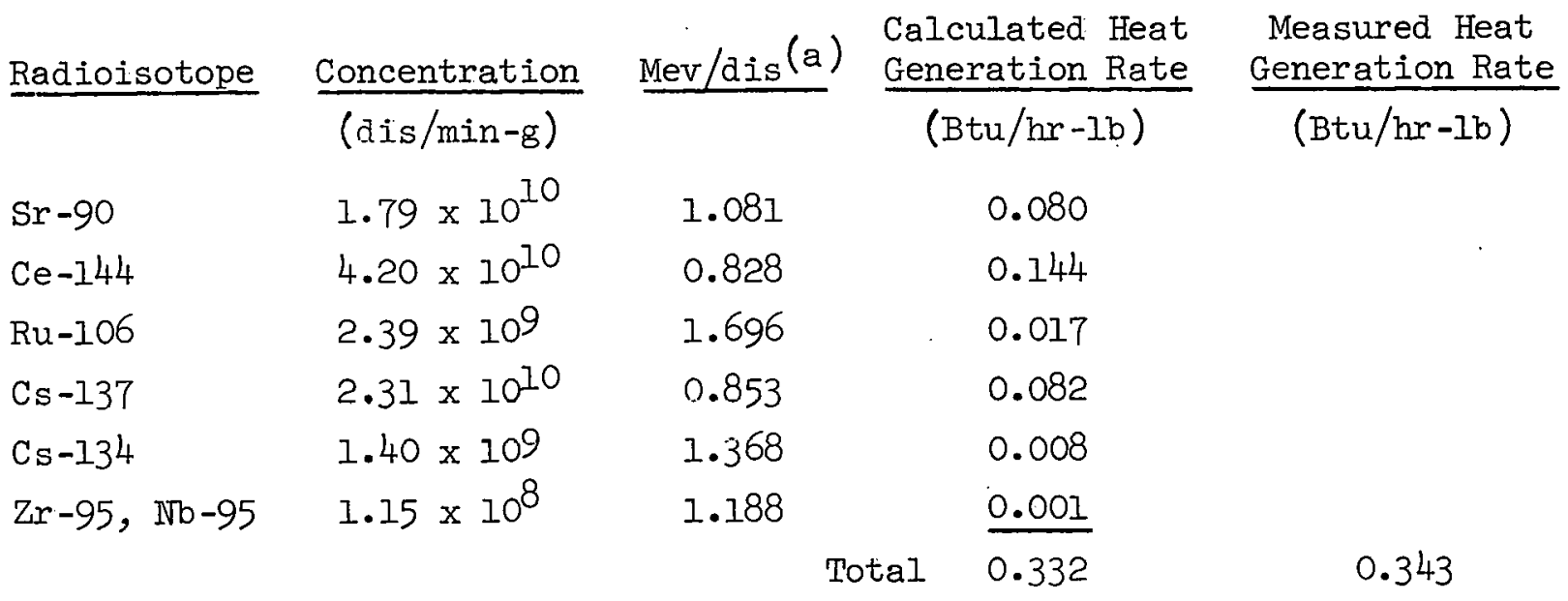

Waste No. WM-185 (April 1965)

\begin{tabular}{|c|c|c|c|c|}
\hline $\operatorname{Sr}-90$ & $2.97 \times 10^{10}$ & 1.081 & 0.140 & \\
\hline $\mathrm{Ce}-144$ & $7.13 \times 10^{9}$ & 0.828 & 0.024 & \\
\hline $\mathrm{Ru}-106$ & $1.17 \times 1.0^{8}$ & 1.696 & 0.001 & \\
\hline Cs -137 & $3.72 \times 10^{10}$ & 0.853 & 0.131 & \\
\hline $\mathrm{Cs}-134$ & $0.98 \times 109$ & 1.368 & 0.006 & \\
\hline $\mathrm{Zr}-95,100-95$ & $<1.23 \times 10^{8}$ & 1.188 & -- & \\
\hline & & Total & 0.302 & 0.303 \\
\hline
\end{tabular}

(a) Blomeke, J. O. and M. F. Todd, Uranium-235 Fission-Production as a Function of Thermal Neutron Flux, Irradiation Time, and Decay Time. I. Atomic Concentrations and Gross Totals, ORNL-2127, Part I, Vol. 1, pp 13-25 (August 19, 1957). 
VII. RFFERINNCES

1. Bower, J. R., Editor, Chemical Processing Technology Quarterly Progress Report, April-June, 1964, ID0-14646 (January 1965).

2. Myers, I. T., "Improved Method of X-Ray Calorimetry", Rev. Sci. Instr. 29, 758 (1958).

3. OtIet, R. I. and D. R. Lewis, "The Use of an Adiabatic Calorimeter for the Measurement of the Disintegration Rate of Cobalt-90", AERE M 1210 (1963).

4. Newsome, J. W. et al, "Alumina Properties", Technicral Paper No. 10, Alumirum Company of America (1960). 


\section{PHILLIPS PETROLEUM COMPANY}

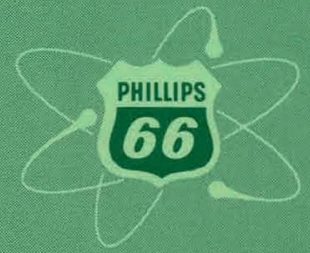

ATOMIC ENERGY DIVISION 